\title{
Языковая личность автора в проекции XXI века: \\ Чехов и мы
}

Петрова Н.Ю. ${ }^{i}$

\begin{abstract}
The article attempts to assess A. Chekov's intellectual heritage and biographical data from the XX-th century perspective. The author focuses on A. Chekov's artistic method as reflected in his language personality (dialogism, openness to interpretation), as well as on his impact on today's multicultural world. Based on cultural and semiotic approach, the research highlights A. Chekov's treatment of the universal concepts of Man, Morals, Feelings, Emotions, Refinement which are analyzed and illustrated.
\end{abstract}

Key words: Chekov, intellectual heritage, new method, cultural and semiotic approach, concepts

Внутренний замысел предлагаемой статьи - навести фокус «камеры истории» и, приблизив к нам далекий XIX век, попытаться несложно рассказать о сложном: о языковой личности и художественном методе Антона Чехова русского писателя-интеллигента, которого ассоциируют с заложением импрессионизма и техники потока сознания, близких к тому времени, в котором живем с вами мы. Хотя Чехов по историческому времени совпадает с Л. Толстым, интуитивно он кажется нам намного современнее. Несмотря на удаленность эпохи, диалог с Чеховым вполне реален благодаря особому свойству его письма, которое, в духе М. Бахтина, принято называть диалогичностью и открытостью для интерпретации.

А. Чехов родился давно, почти 150 лет назад, за свою короткую жизнь длиной в 44 года написал более 900 рассказов, повестей и несколько пьес, прославивших его на весь мир, и умер, не застав исторических переворотов XX века, так сильно повлиявших на многих его современников, например, А. Блока или И. Бунина. Чеховское творческое наследие составило Полное собрание сочинений и писем в 30-ти томах, вышедшее уже после II-ой Мировой войны объемом приблизительно в 12000 страниц - немало для того, кто, страдая с детства туберкулезом, планировал посвятить свою жизнь медицине и поддался внутренней тяге к литературе и театру во вполне сознательном возрасте.

Как любое раздумье, воспоминание, интроспекция, диалог-размышление о Чехове неминуемо превращается в воспоминание о самом себе - в том смысле, что изложение тех или иных фактов всегда видятся сквозь призму собственного опыта, оценки и впечатлений как принятого угла зрения и фокусировки внимания и интересов. Как я воспринимаю Чехова? В каком возрасте я начал его читать? Что в нем люблю? Что не принимаю? Какие его пьесы видел в театре? 
Какие чеховские фразочки осели в памяти? Нельзя не вспомнить «Если в 1-м акте на сцене висит ружье, то в последнем оно должно выстрелить», а таких афоризмов у Чехова не менее 100! Если провести психолингвистический эксперимент, каждому будет, что сказать, и ответы, конечно, будут разные, но объединит их одно - признание таланта и новаторства Чехова, оставленного нам бесценного интеллектуального богатства.

Высоко оценивая своего современника, Л. Толстой считал технику Чехова гораздо выше своей. В то же время Марине Цветаевой - как, впрочем, и Анне Ахматовой - умный и сложный художник Чехов казался скучным моралистом. Они не понимали и не чувствовали его поэзии, хотя чеховское море и духота в «Даме с собачкой», туманный лунный вечер в «Верочке», осень в «Трех сестрах»все дышит поэтической силой. Критики нередко называли Чехова холодным и индифферентным, игнорируя его художественный метод свидетеля жизни. При жизни его критиковали за затянутость, длинноты пьес, а позже ахрония стала его фирменной маркой. В целом, Чехов не умещался в традиционных рамках, и это приводило его современников в замешательство, хотя они не могли не признавать его мастерства. Такая разноречивость мнений подсказывает нам, что вряд ли в своей оценке стоит всерьез доверяться экспертному мнению других. При этом и авторефлексия имеет свои недостатки, поскольку страдает субъективизмом.

Таким образом, поставленную задачу мы решаем не с привычных позиций литературной критики, а в более близком мне концептологическом и шире культуролого-семиотическом - ключе. А значит, с учетом тех современных веяний и тенденций, для которых основным центром становится человек и его восприятие окружающего мира, а художественное произведение рассматривается как фрагмент конструированного вымышленного мира. Такой путь усвоения накопленного в мире знания на сегодня - едва ли не самый продуктивный. Чтобы быть понятой, остановлюсь на проблеме новых подходов к языку в XXI веке.

Большинство традиционных разделов филологии как науки о любви к

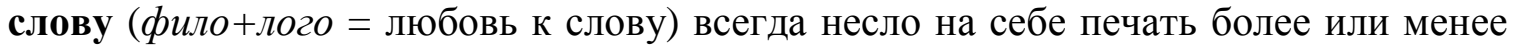
выраженного переплетения разных составляющих, также его любивших. Такой синкретизм объясняется тем, что история языка неотделима от истории народа, культура речи - от культуры общества, фонетика - от физиологии речи и т.д. В результате, в современном мире появились «сдвоенные» науки, названные по бинарному принципу: лингвокультурология, лингвопоэтика, психолингвистика, когнитивная лингвистика и даже когнитивное литературоведение. Нарушения 
границ в сторону психологии, культурологии, семиотики искусств, в целом, сегодня уже не принято рассматривать как факты агрессии. Интеллектуальное богатство языка - это необозримый пейзаж, а не ряд маленьких садиков, отгороженных стенами недоверия. Именно поэтому Российская Академия Наук последнее время организует мероприятия на стыке различных наук с привлечением ученых самых разных сфер и специальностей.

Так, в апреле этого года Институт языкознания РАН, Московская консерватория и факультет психологии МГУ совместно провели 4-х дневную международную конференцию «Живое слово - голос, движение, жест» на своих двух площадках у Кремля (Воздвиженка и Моховая) и как вечер перформансов в дворцах Санкт-Петербурга. Разумеется, говорили о красоте и точности чеховского слова, где ближайший путь - всегда через театр. Вдохновителями такого мощного мероприятия стали лингвисты, литературоведы, редакторы журналов, психологи, искусствоведы, дирижеры, поэты и даже физики и математики - само по себе явление уникальное, если учитывать традиционный консерватизм науки.

К имени Чехова обращаются и тогда, когда речь конкретно заходит о русском языке и культуре речи, как это произошло в прошлом мае на нескольких международных конгрессах, посвященных языку и межкультурной коммуникации, где мне также посчастливилось быть участником. География мероприятий не может не поразить своей широтой: от Великого Новгорода, центра земли русской, с ее древними серебряными куполами и разлившимися озерами до Шанхая - города, олицетворяющего своим обликом технокультуру XXI века. Общее ощущение участников совпало: в сегодняшнем мире компьютеров, ай-педов и ноутбуков культура необходима человеку, как воздух. В русской культуре Чехов признанный авторитет жанра короткого рассказа, по-прежнему самый известный русский драматург в мире, за 100 лет не уступивший место ни одному из возможных соперников. Чем это можно объяснить?

Следуя идее испанского философа и социолога Х. Ортега-и-Гассета, «каждая эпоха привносит с собой свое истолкование человека, принципиально отличное от предыдущего. Вот почему у каждой эпохи - свой излюбленный жанр» [Ортега-и-Гассет 1974: 173-174]. В европейской литературе XIX века таким широким углом зрения, представлявшим важнейшие аспекты жизни человека, его эстетические темы, несомненно, был роман. В русской литературе также прослеживалась традиция «большого полотна». Живший в это время Чехов писал только рассказы, короткие повести, похожие на рассказы, пьесы, похожие на 
повести, и роман с крупными фигурами по типу Онегина или Печорина, говоря чеховским языком, «не вытанцовывался». Традиция ломалась.

Чехов жаловался Бунину: «Вам хорошо теперь писать рассказы, все к этому привыкли, а это я пробил дорогу к маленькому рассказу». На самом деле, рассказы Чехова - это целостная повествовательная система, посвященная теме России. Здесь можно найти и перспективу русского города, и деревни, и реки и леса до самого Сахалина, где великое российское пространство дышит чувством свободы, а герой восклицает: «Неужели в России так много людей? Батюшки!» Действительно, Чехов - один из самых «населенных» писателей мировой литературы: если у Бальзака 3000 персонажей, то у Чехова в 900 рассказах и пьесах, написанных за 26 лет, их 8000. Его уникальный стиль - тысячи элементарных отражений в едином повествовании со сквозным сюжетом.

Героев Чехова, как правило, представлены в виде беглых набросков в 2-3 штриха. Для литературной традиции такая краткость считалась непозволительной и свидетельствовала об упрощении проблемы - ведь эпоха с маленькими людьми и мелкими эмоциями безгеройна. Глазами сегодняшнего наблюдателя можно сказать: в рассказах Чехова развивалась тема маленького человека, тема Гоголя и Достоевского, поднявших их малость до трагедии. По Чехову, нельзя унижать человека, и все в нем должно быть прекрасно: и лицо, и одежда, и душа и мысли - еще одна известная цитата.

На самом деле, Чехова интересовали просто люди, представленные в будничном течении жизни, и в этой простоте он видел их сложность. Люди различных возрастов и социального уровня живут в разных потоках времени, которые движутся не параллельно и не с одинаковой скоростью, а создавая встречные временные потоки - хронотопические проекции вперед и назад. Малый формат литературного жанра рассказа с его краткостью, лаконичностью, обозримостью и монофокусностью позволил писателю приблизить камеру и показать то или иное явление крупным планом, нередко в юмористическом ключе:

- Толстый и Тонкий как внешне и социально контрастирующие антиподы,

- Хамелеон, где в облике одного показана двуликость многих,

- Анна Серегеевна и Гуров из «Дамы с собачкой», герои рассказа «О любви» как жизнь в зеркале.

Чехов, несомненно, обладал природным даром наблюдателя, который позволил ему создать калейдоскоп художественных фотографий реальности. Все 
началось с детства: Таганрог, сотни километров от Москвы, в семье семеро детей (шесть братьев, одна сестра, Чехов - третий), вокруг провинция и пошлость. Как человек из провинции, Чехов всегда ассоциировал далекую столицу с мечтой, а герои его пьесы «Три сестры» будут восклицать: «В Москву! В Москву».

Конечно, после Таганрога будет Москва, а пока семья живет бедно, дети все время хотят есть. Позже в своем огромном вишневом саду в имении Мелихово Чехов воскликнет: «Неужели это все мое?!», «Неужели я сам все это могу съесть?!». Отсюда и смешное, и грустное высказывание «В детстве у меня не было детства». Из детства, которого «не было», пришли многочисленные воспоминания, многие из них, связанные с едой - отец Чехова был владельцем мелкой лавки, где дети помогали ему торговать всякой снедью. Однажды в бочке с подсолнечным маслом оказалась крыса. Чтобы товар не пропал, отец пригласил священника, который освятил бочку. После благословления торговля продолжилась своим чередом. Вот такая реальность.

Говоря о чеховских пространствах, нельзя не упомянуть Сахалин. Широте авторского кругозора способствовало и длительное путешествие Чехова по Сибири до Сахалина в 1890 году - факт не всегда известный искушенному читателю. Чехов провёл настоящую перепись населения Сахалина, собрав 10000 карточек о жителях острова, в том числе и о политических заключённых, эта перепись была опубликована только в 2005 году. Обратный путь лежал по Индийскому океану через Суэцкий канал с остановкой на острове Цейлон - домой, в Россию.

Любопытно, но почти все русские темы Чехова обнаруживаются в Словаре «Константы русской культуры» академика Ю.С. Степанова (1997), который стал первым в литературе опытом систематизации ценностей культуры. Это концептыуниверсалии, константы, которые не подвергаются временным изменениям и присутствуют постоянно как явления панхронии: ПРАВДА, ЗАКОН, ЛЮБОВЬ, ДУША, ИНТЕЛЛИГЕНЦИЯ. В словаре они выявляются в своих истоках и прослеживаются через взгляды мыслителей, писателей и рядовых членов общества наших дней. Здесь заново проступают моральные лики Достоевского, Чехова, Колчака и др. Примеры обнаруженных нами констант творчества Чехова:

- ЧЕЛОВЕК: свободный человек, личность, личное социальное достоинство, душа, ангел, гений, харизматическая личность, второе я, чины, «табель о рангах» как параметризированное пространство (архаизмы типа Вашество как Ваше превосходительство или позвольте ручку в этикетном значении позвольте поцеловать ручку, 
а не дайте ручку, мне писать нечем, в качестве примера может служить рассказ «Смерть чиновника»);

- РУССКИЙ ЧЕЛОВЕК через описание СОСТОЯНИЙ и ЧУВСТВ: вера, доверие, грех, грусть, жалость, искупление, любовь, страхтоска, цель, чувство личной свободы. Все эти русские скучно, жалко, тошно;

- МОРАЛЬ: совесть, стыд;

- ИНТЕЛЛИГЕНТНОСТЬ.

Чехов и сам константа, прежде всего как прототипический образ интеллигента. В России возникновение интеллигенции принято связывать с серединой XIX века, т.е. с отменой крепостного права. Исторически к классу интеллигенции причисляют представителей «свободных» профессий, таких как адвокат, врач, художник в широком смысле этого слова и выделяют стремление интеллигенции сохранить высоты культуры перед лицом торжествующей бюрократии и полуобразованности масс. Чехов был и врачом (учился в московском университете у Склифосовского), и писателем. Ему были свойственны не только образованность, но и тревога, свобода мысли, совесть, гуманизм. По О. Мандельштаму, например, интеллигент должен быть открыт и к поэзии. Интересно, что по своей внутренней форме слово «интеллигенция» (ср. англ. intellect, intelligence) представляет уникальный случай выделения общественного класса по признаку высшей степени разума, или интеллекта.

Еще более чем в рассказах, Чехова-интеллигент проступает в пьесах. На самом деле, вся жизнь писателя была крепко привязана к театру: его жена Ольга Книппер-Чехова - известная актриса МХT, где Станиславский и НемировичДанченко ставили его пьесы. Логотип театра - чайка - пришел из одноименной чеховской пьесы. Именно поэтому памятник Чехову в Москве поставлен перед зданием МХT.

Опыт написания юмористических рассказов помог Чехову модифицировать столь любимый им водевильный жанр (пьесы «Свадьба», «Медведь») через блестящие компактные реплики и диалоги героев. Достаточно вспомнить реплику Смирнова из «Медведя»: «Двенадцать женщин я бросил, девять бросили меня»!

Многие идеи пьес появлялись не только из рассказов, но и в качестве реальных наблюдений. Так, знакомый Чехова Лейкин купил имение графов Строгановых, сказав почти словами из «Вишневого сада»: «Прежде здесь хозяевами были графы, а теперь - я, хам». Сам же Лейкин изумлялся скромности 
Мелихова и отсутствию у Чехова задатков барина и качеств буржуа. Зато там цвел чеховский вишневый сад.

Пьеса «Вишневый сад» - вершина творчества чеховской драматургии, где как нельзя ясно чувствуется называемое чеховское настроение: беспечальное отчаяние, чувство вины, беззащитность перед силой и обманом по принципу «Будь что будет, поскорее бы в Париж!» Действие происходит в имении Раневской, бутафория - прадедовские вещи. Персонажи съезжаются, хотя события происходят за сценой, а на самой сцене никакого действия нет - все ждут. Пьеса задумана как четырехактная пауза, наполненная звуками ворчания, восклицаний, жалоб, молчания и тоски, и трудна и для актеров, и для зрителей. Первым играть почти нечего: полутона, полушепот, вполголоса, без яркой жестикуляции.

В отличие от рассказов, в которых мало метафорически-отвлеченного, пьеса - сгусток символов, и зрителям нужно следить за психологическим подтекстом. Этот сложный мир символов отражает тайну истекшего времени, где все населено воспоминаниями и тенями, поэтому и жанр «Вишневого сада» можно определить, как мифологическая комедия. Сад символизирует труд и время: следы времени остаются в годовых кольцах деревьях, как в генетических картах человеческого рода. Как и все другие произведения, пьеса «Вишневый сад» глубоко нетрадиционна и обращена к новым поколениям. Оттолкнувшись от Ибсена и Метерлинка, Чехов предает эстафету Шоу, Пристли и О’Нилу и их зрителям.

Завершая свои размышления, хочу выразить надежду, что исследователи творчества Чехова смогут создать Паралингвистический словарь Чехова по типу словаря языка А.С. Пушкина, языка Ф.М. Достоевского, рифм М.Ю. Лермонтова, эпитетов И.А. Бунина. Такое собрание могло бы четче проследить весь языковой и философский опыт великой русской константы - Антона Чехова и продолжить, в его духе, «беседовать и вспоминать».

\section{Библиография}

Opmeza-u-Гассет, X. Краткий трактат о романе [Текст] / Х. Ортега-и-Гасет // Вопросы литературы. - 1987. - № 9. - С. 169-205.

Степанов, Ю.С. Константы. Словарь русской культуры. Опыт исследования [Текст] / Ю.С. Степанов. - М.: Языки русской культуры, 1997. - 824 с.

Чехов, А.П. Полное собрание сочинений и писем [Эл. ресурс] // Режим доступа: http://lib.rus.ec/s/25067. Дата обращения: 09.10.2012. 


\footnotetext{
і Петрова Наталья Юрьевна / Petrova Natalia Yurievna.

Кандидат филологических наук, доцент кафедры английской филологии факультета английской филологии; докторант Института языкознания РАН Институт иностранных языков ГОУ ВПО «Московский городской педагогический университет» natalia-yu-petrova@yandex.ru
} 